\title{
Diexsis in Novel Bumi Manusia and Bukan Pasar Malam by Pramoedya Ananta Toer
}

\author{
Abelian Jordi Wicaksono, Retno Winarni, Muhammad Rohmadi
}

\author{
Master of Indonesian Language Education, Sebelas Maret University, Surakarta, Indonesia \\ Received: 11 Sept 2020; Received in revised form: 18 Nov 2020; Accepted: 25 Nov 2020; Available online: 07 Dec 2020 \\ (C)2020 The Author(s). Published by Infogain Publication. This is an open access article under the CC BY license \\ (https://creativecommons.org/licenses/by/4.0/).
}

\begin{abstract}
The purpose of this study is to describe the form of deixis used by Pramoedya Ananta Toer in his novels. This study used a qualitative descriptive method with documentation analysis techniques and interviews to collect the data. The results of this study refer to a pragmatic study, namely the form of deixis. The conclusion of the study shows that the form of deixis found in the two novels uses different functions so that this indicates that speakers are able to convey certain meanings to speech partners, making it easier for speakers and speech partners to convey and understand the speech.
\end{abstract}

Keywords - Pragmatics, Deixis Form, Novel, Pramoedya Ananta Toer.

\section{INTRODUCTION}

Language can be used as a tool for expression and also interacting both in writing and orally. The use of language can be said to be appropriate if it is in accordance with the situation and conditions of the speech. The form of language used is usually also influenced by a number of factors. This makes communication a supporting factor in social life as well as a means of conveying information. Through the communication process, speech events and speech acts emerge. Moreover, in the area of education, the use of Indonesian language is set in the Act No. 24 of 2009 concerning the flag, language and symbols of the country.

Pragmatics is the science of language that studies the use of language that is associated with context. The meaning of the language can be understood if the context is known. Pragmatics boundaries are the rules of using language regarding the form and meaning associated with the speaker's intent, context, and circumstances. Several pragmatics research has been done before. [1] Allan discusses pragmatic and pragmatic objects. [2] examines a wide range of topics, including lexical semantics, compositional semantics, and pragmatics. [3] Yule explains that pragmatics is the study of the meaning conveyed by a speaker and interpreted by a listener or reader. In addition, [4] Rescher discusses the problem of investigation and pragmatics cognition in a practical, theoretical, and more complex way than previously known knowledge theorists. Moreover, pragmatics tries to describe utterance delivered by a speaker or addresser by interpreting the intended meaning.

[5] Gruyter examines the acquisition of Japanese language, the acquisition of Japanese language for foreign speakers including pragmatics and communicative competences. Furthermore, [6] Haunt's research discusses what is often called as pragmatics thinking and learning.

Deixis is a form of language, either in the form of words or phrases, which function as pointers that refer to certain things or functions outside of language. The pragmatics study of deixis is divided into six parts, namely person deixis, place deixis, pointer deixis, time deixis, discourse deixis, and social deixis [7]. Previously, Burhan Nurgiyantoro had analyzed the use of social deixis in the Novel Trilogy of "Ronggeng Dukuh Paruk", "Lintang Kemukus Dini Hari" and "Jentera Bianglala" in 1990.

[8] Wijana, based on the results of his research, divides persona deixis into five forms, namely the first single persona, the plural persona, the second single persona, the third single persona, and the third plural persona. Furthermore, this research will discuss three forms of deixis, namely person deixis, place deixis, and time deixis in the novel by Pramoedya Ananta Toer, namely "Bumi Manusia" (1980) and "Bukan Pasar Malam" (1951). Both novels show strong characteristics in the use of person deixis, place deixis, and time deixis. Therefore, the results 
of this study are expected to give contribution to the development of pragmatic studies, especially in the implementation of deixis in literary works. The results of this study resulted in a detailed description of the use of person deixis, place deixis, and time deixis as a way to understand a deeper meaning from the novel by Pramodya Ananta Toer.

\section{METHOD}

This research uses descriptive method with a qualitative approach. The data analyzed is descriptive in nature as the data collected is in the form of words to make a systematic description. Thus this study uses a qualitative descriptive method to analyze the form of deixis contained in two novels by Pramodya Ananta Toer. Data collection techniques used in this study were documentation analysis and interviews. This technique is used to collect data from novels as well as information from interviews that have something to do with research.

\section{RESULTS AND DISCUSSION}

Researchers will discuss and examine three forms of deixis, namely personal deixis, place deixis, and time deixis using the theory described by Purwo [9]. By using this theory, the description of deixis examples can be presented more clearly. In addition, this theory has been widely used by previous researchers as the main reference for deixis research theory. in addition, the theories of other linguists will be used to complement the discussion in this study.

\section{Persona Deixis (Person)}

[9] Purwo explains that persona deixis is a reference that is indicated by a pronoun, depending on the role played by the speech act participant. The person who is speaking has a role called the first persona. If he does not speak again, and then becomes a listener, he changes roles and is called the second persona. People who are not present at the place of conversation (but become the subject of conversation), or who are present close to the place of conversation (but are not actively involved in the conversation itself) are called the third persona.

\section{a. Persona deixis (Novel Bumi Manusia)}

A: "Mengapa tak kau ambil semua untuk dirimu sendiri? Santapan pagi dan dewi itu?'

B: "Aku? Ha-ha. Untukku hanya dewi berdarah Eropa tulen!'

(Toer, 2005: 21-23. Bumi manusia)[10]
The first personal pronouns used in utterances $\mathrm{A}$ and $\mathrm{B}$ indicate different references. In utterance $\mathrm{A}$, the word "kau" by A is meant to refer to speaker B. while in utterance B, the word "aku" refers to speaker B himself. In addition, in utterance $A$ the referent pointed by $\{-m u\}$ is $B$, and in utterance $\mathrm{B}$ the referent pointed by $\{-\mathrm{ku}\}$ is $\mathrm{B}$.

A: "Kau memperolok aku, Rob."

B: “Tidak. Pada suatu kali kau akan jadi bupati, Minke."

(Toer, 2005: 21-23. Bumi manusia)[10]

The first personal pronouns used in utterances $\mathrm{A}$ and $\mathrm{B}$ denote different referents. In utterance A the word "kau" refers to speaker B, whereas in utterance B the word "kau" refers to speaker A.

\section{b. Persona deixis (Novel Bukan Pasar Malam)}

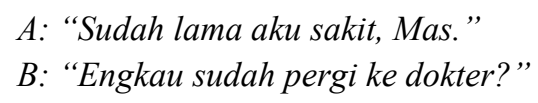

The first personal pronouns used in utterances A and $\mathrm{B}$ denote different referents. In utterance $\mathrm{A}$ the word "aku" refers to himself, namely speaker A, while in utterance B the word "engkau" refers to speaker A.

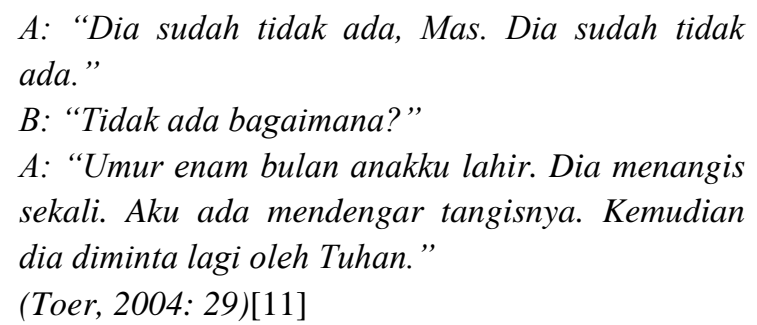
sekali. Aku ada mendengar tangisnya. Kemudian dia diminta lagi oleh Tuhan."

(Toer, 2004: 29)[11]

The personal pronouns used in utterance $A$ indicate different references. In utterance $\mathrm{A}$, the word "dia" is meant to be the third persona (a person who is not present at the place of the conversation but becomes the subject of the conversation). In addition, in utterance A the use of the word "aku" by A means to refer to himself, namely speaker A.

\section{Place Deixis}

Place deixis or space deixis is a category of deixis which designates the location of the object or the reference where the object is located. To determine the location of an object, a central point of spatial orientation is needed, namely where the speaker is located.

\section{a. Place deixis (Novel Bumi Manusia)}

Dokar tiba-tiba membelok melewati pintu gerbang, melewati papan nama Boerderij Buitenzorg, langsung menuju ke tangga depan rumah. 
A: "Ke sini?"

B: (hanya mendengus)(Toer, 2005: 25)[10]

The word "ke sini" is a deixis of place as it refers to the previous sentence describing a place (melewati pintu gerbang, melewati papan nama Boerderij Buitenzorg, langsung menuju ke tangga depan rumah).

\section{b. Place deixis (Novel Bukan Pasar Malam)}

\section{A: "Bagaimana kalau Bapak tinggal di rumah saja?" \\ B: "Di sini, anakku, para perawatnya masih kanak- kanak semua."(Toer, 2004: 73)[11]}

Speaker A utters the word "di rumah" which is a place deixis as it refers to the location of a place. Speaker B also mentions the word "di sini" which refers to the location where speakers A and B have a conversation.

\section{Time Deixis}

Time deixis is a category of deixis which is used to designate time as intended in the speech. Time deixis is single dimensional and unidirectional. Spatial lexemes such as depan 'front', belakang 'back', panjang 'long', pendek 'short' used in the sense of time give the impression as if time is a still thing.

\section{a. Time deixis (Novel Bumi Manusia)}

A: "Sekarang sedang ada pesta besar, mengapa mereka tak diberi libur?"

B: "Mereka boleh berlibur kalau suka. Mama dan aku tak pernah berlibur. Mereka pekerja harian."(Toer,2005: 45)[10]

The word "sekarang" indicates the current or present time when the dialogue took place.

\section{b. Time deixis (Novel Bukan Pasar Malam)}
A: "Kapan engkau datang?"
B: "Jam duabelas siang tadi, Bapak."

(Toer, 2004: 31)[11]

The phrase "kapan engkau datang?" in utterance A is used to ask for the time. while the phrase "jam duabelas siang" in utterance B is used to answer A's question that said he came at twelve in the afternoon.

\section{CONCLUSION}

This research can be concluded based on the findings of the analysis of the form of deixis contained in two novels by Pramodya Ananta Toer. In these two novels, Pramodya Ananta Toer uses three different types of deixis, namely person deixis, place deixis, and time deixis. The deixis in the two novels has different functions. This results in speakers being able to convey certain meanings accurately to the speech partner. Based on this explanation, it can be seen that the two novels by Pramodya Anata Toer are linguistically easy to understand because the arrangement of the use of different types of deixis in these novels makes it easier for the reader to grasp the intention of the speaker or addresser, and speech partners or addrressee in delivering and understanding utterances according to the intended meaning and purpose.

\section{REFERENCES}

[1] K. and J. Allan, The Cambridge Handbook of Pragmatics. Amerika: Cambridge University Press, 2012.

[2] P. R. Kroeger, Analyzing Meaning an Introduction to Semantics and Pragmatics. Berlin: Language Science Press, 2018.

[3] G. Yule, Pragmatik. Yogyakarta: Pustaka Pelajar, 2014.

[4] N. Rescher, Cognitive Pragmatism: The Theory of Knowledge in Pragmatic Perspektive. United States of America: University of Pittsburgh Press, 2001.

[5] de M. Gruyter, Pragmatic Competence. Berlin: Library of Congress Cataloging-in- Publication Data, 2009.

[6] A. Haunt, Pragmatic Thinking and Learning Refector your "Wetware." Texas: The Pragmatic Bookshelf, 2008.

[7] I. B. Putrayasa, Pragmatik. Yogyakarta: Graha Ilmu, 2014.

[8] I. D. P. dan M. R. Wijana, Analisis Wacana Pragmatik Kajian Teori dan Analisis. Surakarta: Pustaka Pelajar, 2011.

[9] B. K. Purwo, Deiksis dalam Bahasa Indonesia. Jakarta: Balai Pustaka, 1984.

[10] P. Ananta Toer, Bumi Manusia. Jakarta Timur: Lentera DiPantara, 2005.

[11] P. Ananta Toer, Bukan Pasar Malam. Jakarta Timur: Lentera DiPantara, 2004. 